\title{
Intraductal Hepatocellular Carcinoma Leading to Obstructive Jaundice
}

\begin{abstract}
Raquel D Greca ${ }^{1 *}$, Marlone Cunha-Silva ${ }^{1,3}$, Larissa BE Costa², Tiago Sevá-Pereira',3 and Ilka FSF Boin ${ }^{3,4}$
${ }^{1}$ Division of Gastroenterology (Gastrocentro), University of Campinas (Unicamp), Brazil
\end{abstract}

${ }^{2}$ Department of Pathology, University of Campinas (Unicamp), Brazil

${ }^{3}$ Unit of Liver Transplantation, Hospital de Clínicas, University of Campinas (Unicamp), Brazil

${ }^{4}$ Department of Surgery, University of Campinas (Unicamp), Brazil

Submission: February 10, 2021; Published: February 25, 2021

*Corresponding author: Raquel Dias Greca, Division of Gastroenterology (Gastrocentro), University of Campinas Rua Carlos Chagas, 420. Cidade Universitaria / Campinas, São Paulo, Zip code 13083-878, Brazil

Keywords: Liver cancer; Bile duct obstruction; Liver transplantation; Cytokeratin 19; Jaundice

\section{Case Description}

A 48-year-old man with metabolic-dysfunction associated fatty liver cirrhosis was first on the transplant waitlist. Upon hospital admission, he complained of jaundice over the past month. Laboratory: total bilirubin $31.6 \mathrm{mg} / \mathrm{dL}$ (normal range $<1.2)$; direct bilirubin $25.7 \mathrm{mg} / \mathrm{dL}(<0.2)$; alkaline phosphatase $200 \mathrm{U} / \mathrm{L}(<104)$; international normalized ratio $1.64(<1.25)$.
Serum alpha-fetoprotein was normal and all cultures were negative. Both ultrasound, tomography and magnetic resonance cholangiography (Figure 1) showed a biliary dilation of the right hepatic lobe, with no evidence of an obstructive factor. He had a normal enhanced tomography for hepatocellular carcinoma (HCC) surveillance (because of obesity) two months before. With no signs of infection, a transplantation was performed.

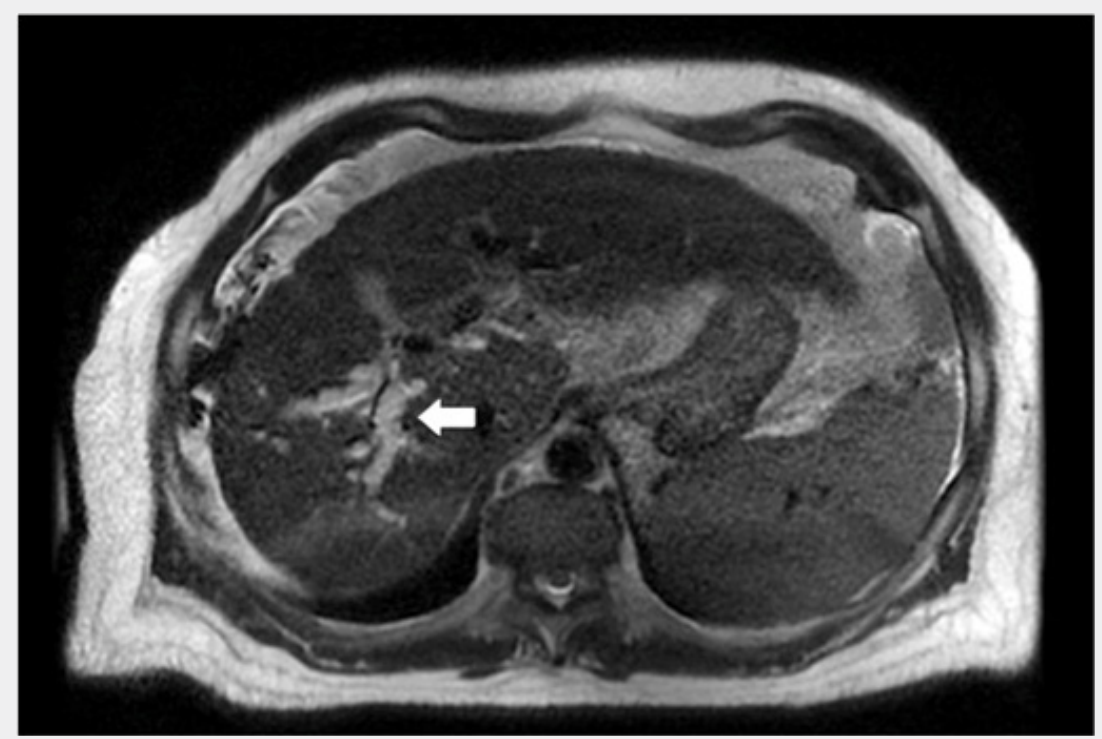

Figure 1: Axial section magnetic resonance cholangiography: dilation of intrahepatic biliary ducts in the right lobe (white arrow), with no identifiable obstructive factor. 
The explant analysis evidenced a moderately differentiated HCC measuring $3.0 \times 2.5 \times 2.5 \mathrm{~cm}$ in the segment VIII (Figure 2A) with an intraductal biliary invasion (Figure 2B), and liver cirrhosis. No angiolymphatic spread was observed (Figure 3A). On immunohistochemistry, CK-7 and CD-56 marked the tumor but CK-19 was only expressed in the biliary epithelium (Figure 3B).

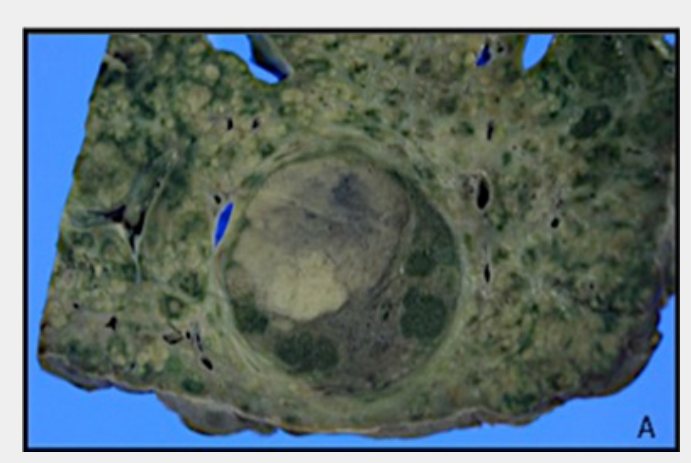

Figure 2A: Gross section of hepatocellular carcinoma in severe cirrhosis (Laennec's classification 4C) with greenish coloration of the adjacent parenchyma due to cholestasis.

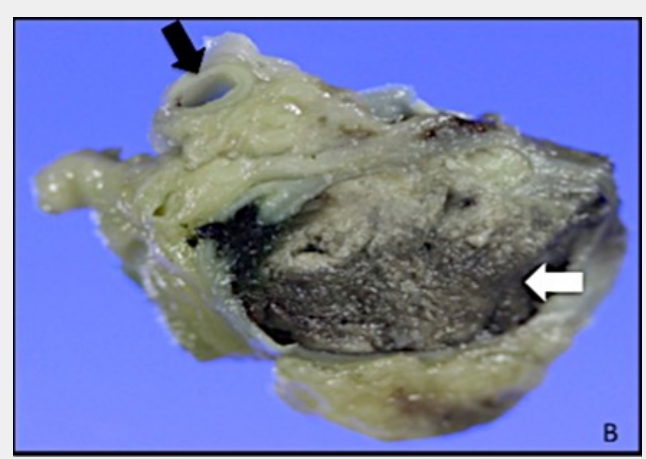

Figure 2B: Tumoral mass (white arrow), measuring $2.8 \mathrm{~cm}$, occupying the common hepatic duct. Notice the vascular branches: hepatic artery (black arrow) and adipose tissue of the hilum.

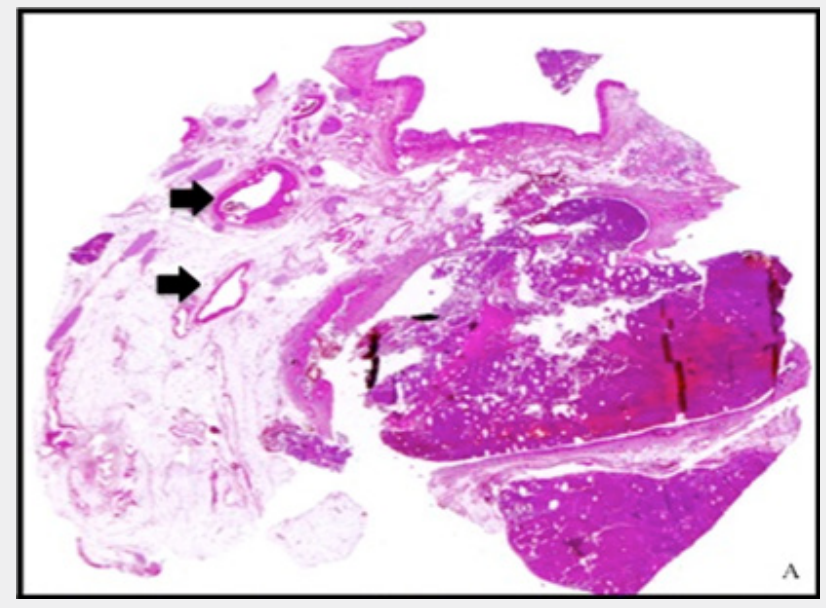

Figure 3A: Histological analysis: hepatocellular carcinoma with intraductal invasion. Vascular branches (black arrows) do not show carcinomatous emboli (hematoxylin-eosin, panoramic view of scanned image).

Obstructive jaundice as a first HCC clinical feature is uncommon (2\%-8\%) [1]. Some patients present liver failure or advanced tumors [2,3]. Intraductal biliary invasion of a respectable HCC is extremely rare $[4,5]$. In our case, biliary obstructive hepatopathy 
was present, related to the intraductal involvement of HCCwhich led to MELD worsening and enabled a faster transplant.

In order to improve the assessment, physicians may prefer to treat biliary obstruction with endoscopic prostheses, since it remains a challenge to find out whether surgical resection or transplant would be more appropriate. Our patient had a favorable outcome and is still alive 21 months later.

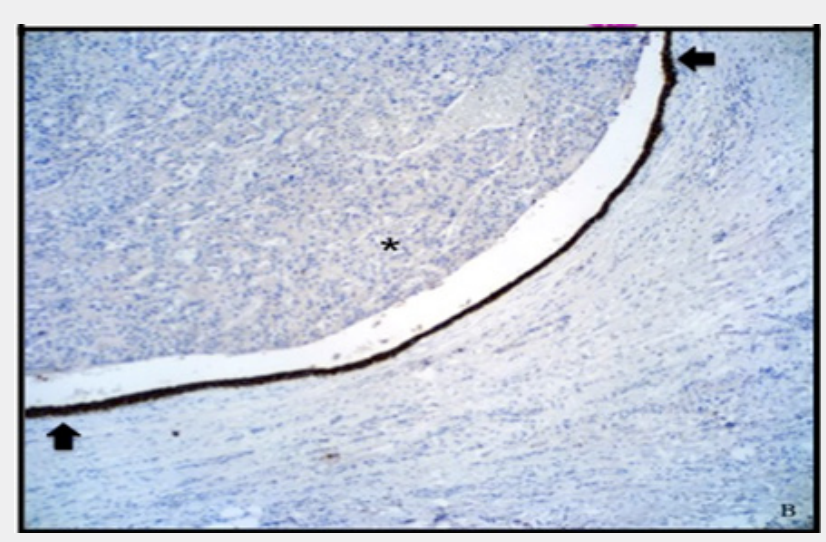

Figure 3B: Immunohistochemistry: cytokeratin-19 staining marked in the biliary epithelium (black arrow), without expression in hepatocellular carcinoma $\left(^{*}\right)$.

\section{Description of Financial Support or Competing Interests}

The authors received no specific funding for this work.

The authors have declared that no competing interests exist.

\section{Description of Author's Contributions}

R.D.G. and M.C.S. contributed substantially to the conception and design of the study and drafting of manuscript. L.B.E.C. performed the histological examination of the liver and was a major contributor in writing the manuscript. T.S.P. and I.F.S.F.B. provided critical revision of the article and final approval of the version to be published.

\section{Confirmation that Informed Patient Consent was Obtained for Publication of the Case Details}

The study was approved by the hospital ethics committee at the University of Campinas (protocol number 28784120.4.0000.5404) and written informed consent was obtained from the patient.

\section{References}

1. Van Dinter TG Jr, Schmidt JF, Tarnasky PR (2011) Obstructive jaundice caused by intraductal hepatocellular carcinoma. Clin Gastroenterol Hepatol 9(9): e94-e95.

2. Qin LX, Tang ZY (2003) Hepatocellular carcinoma with obstructive jaundice: diagnosis, treatment and prognosis. World J Gastroenterol 9(3): 385-391.

3. Lau WY, Leung JWC, Li, AKC (1990) Management of Hepatocellular Carcinoma Presenting as Obstructive Jaundice. Am J Surg 160(3): 280282.

4. Kojiro M, Kawabata K, Kawano Y, Shirai F, Takemoto N, et al. (1982) Hepatocellular carcinoma presenting as intrabile duct tumor growth: a clinicopathologic study of 24 cases. Cancer 49(10): 2144-2147.

5. Bhattarai S, Graham RP, Sigel CS, Shi, J, Gonzalez RS, et al. (2019) Bile duct involvement by hepatocellular carcinoma: A rare occurrence and poor prognostic indicator in bile duct brushing samples. Cancer Cytopathol 127(11): 691-699.

\section{Your next submission with JuniperPublishers will reach you the below assets}

- Quality Editorial service

- Swift Peer Review

- Reprints availability

- E-prints Service

- Manuscript Podcast for convenient understanding

- Global attainment for your research

- Manuscript accessibility in different formats ( Pdf, E-pub, Full Text, audio)

- Unceasing customer service

Track the below URL for one-step submission https://juniperpublishers.com/online-submission.php 